\title{
Zbieg ubezpieczenia powszechnego i ubezpieczenia społecznego rolników
}

\section{Wstęp}

Cechą wyróżniającą aktywność zarobkową Polaków jest liczna populacja dwuzawodowców potocznie zwanych także chłoporobotnikami. Są to osoby spełniające warunki do uznania ich na gruncie ustawy o ubezpieczeniu społecznemu rolników (dalej: u.s.r.) ${ }^{2}$ za rolników, którzy wykonują jednocześnie działalność objętą obowiązkiem ubezpieczenia na podstawie ustawy o systemie ubezpieczeń społecznych (dalej: ustawa o s.u.s.) ${ }^{3}$. Z uwagi na fakt, że ubezpieczenie rolników w KRUS i powszechne ubezpieczenie społeczne w ZUS stanowią dwa odrębne systemy zabezpieczenia społecznego, liczne problemy rodzi ustalenie zasad podlegania przez nich ubezpieczeniu społecznemu. Celem niniejszej publikacji jest analiza zbiegu tytułów ubezpieczenia emerytalnego i rentowego w ZUS oraz KRUS.

\section{Sytuacja społeczna rolników w Polsce}

Znaczny odsetek dwuzawodowców w Polsce spowodowany jest przede wszystkim zaszłościami okresu socjalistycznego. Wprowadzona w latach 1962-1977 zasada renty za ziemię ${ }^{4}$, przymusowe przejmowanie gospodarstw rolnych przez państwo, a jednocześnie opór rolników przed kolektywizacją, doprowadziły do znacznego rozdrobnienia gospodarstw rolnych w Polsce. Okres po 1989 roku cechuje z kolei zaniechanie niezbędnych reform, w tym przede wszystkim konsolidacji gospodarstw rolnych oraz zagospodarowania nadwyżki siły roboczej na wsi przez inne sektory gospodarki. Na obecny stan rzeczy oddziałuje także dysproporcja w wysokości składki na ubezpieczenie społeczne. Osoba wykonująca pozarolniczą działalność opłacała w 2016 roku miesięczną składkę w wysokości 1172 zł 56 gr. ${ }^{5}$, rolnik posiadający gospodarstwo rolne

\footnotetext{
${ }^{1}$ Adiunkt, Uniwersytet Łódzki, Wydział Prawa i Administracji, Katedra Prawa Ubezpieczeń Społecznych i Polityki Społecznej.

${ }^{2}$ Ustawa z dnia 20 grudnia 1990 r. o ubezpieczeniu społecznym rolników, Dz.U. z 2016 r. poz. $277 \mathrm{ze} \mathrm{zm}$.

${ }^{3}$ Ustawa z dnia 13 października 1998 r. o systemie ubezpieczeń społecznych, Dz.U. z 2016 r. poz. 963 ze zm.

${ }^{4}$ B. Wierzbowski, Status socjalny rolnika, [w:] Prawo rolne, A Stelmachowski (red.), Warszawa 2005, s. 311.

${ }^{5}$ http://www.zus.pl/ (dostęp: 01.04.2017).
} 
$\mathrm{o}$ areale poniżej 5 ha przeliczeniowych składkę miesięczną w wysokości $130 \mathrm{zł}^{6}$ w efekcie znaczne rozdrobnienie areałów gospodarstw rolnych utrzymuje się w Polsce do dziś. Z danych GUS wynika, że w rolnictwie, leśnictwie i łowiectwie zatrudnionych jest w Polsce łącznie $2 \mathrm{mln} 150$ tys. osób, tj. 15,5\% aktywnej zarobkowo populacji . Statystyki KRUS ukazują z kolei, że liczba osób objętych ubezpieczeniem społecznym rolników w 2015 roku wyniosła 1 mln 375 tys. osób. Łatwo zatem wskazać, że oficjalna liczba dwuzawodowców to 775 tys. osób.

Warto nadmienić, że dane te nie obejmują licznej grupy rolników pozostających w tzw. szarej strefie. Jak wynika ze statystyk publikowanych przez Kasę, znaczna cześć ubezpieczonych w KRUS gospodaruje na areałach zbyt małych, aby mogły one stanowić dla nich jedyne źródło utrzymania ${ }^{8}$. Dla potrzeb niniejszej publikacji, jako granicę zdolności utrzymania z gospodarstwa rolnego przyjąłem 5 ha przeliczeniowych, a więc najczęściej pojawiającą się w statystykach KRUS powierzchnię, pozwalającą rozróżnić małe i średnie gospodarstwo rolne. W 2009 roku (ostatnie badanie dostępne na stronie Kasy) na areałach o powierzchni poniżej 5 ha przeliczeniowych gospodarowało $58,7 \%$ rolników. Odsetek ten stanowił 893 tys., spośród 1 mln 524 tys. ubezpieczonych w 2009 roku w KRUS. Dodatkowo, działalność rolniczą na areałach poniżej 1 ha przeliczeniowego, prowadziło ok. 15\% rolników to jest 228 tys. osób. Uwzględniając zatem odsetek osób niezdolnych do utrzymania z uwagi na zbyt niski areał gospodarstwa rolnego, można założyć, że rzeczywista liczba dwuzawodowców, uwzględniając także szarą strefę, jest znacznie wyższa i może oscylować nawet wokół nawet $1 \mathrm{mln} 500$ tys. osób.

Nieujawnianie pozarolniczego tytułu ubezpieczenia, wynika przede wszystkim z faktu, iż ubezpieczenie społeczne rolników oparte jest w przeważającej mierze na finansowaniu budżetowym, a ubezpieczenie powszechne na składce finansowanej przez ubezpieczonego i płatnika. Ponadto, istniejąca początkowo dysproporcja pomiędzy wysokością świadczeń z systemów rolniczego i powszechnego stopniowo się zmniejsza, co dodatkowo sprzyja unikaniu przystępowania do ubezpieczenia z pozarolniczych tytułów ubezpieczenia. $\mathrm{Na}$ taki stan rzeczy wpływa także stopniowe rozszerzanie katalogu pozaskładkowych świadczeń, które są przyznawane rolnikom z budżetu państwa. Warto

\footnotetext{
${ }^{6} \mathrm{http}: / /$ www.krus.gov.pl/krus.1/krus-w-liczbach/wymiar-kwartalnych-skladek-na-ubezpieczeniespoleczne-rolnikow/ (dostęp: 01.04.2017).

${ }^{7}$ GUS, Rocznik statystyczny rolnictwa 2015, Warszawa 2015, s. 37.

${ }^{8} \mathrm{~W}$ poszczególnych ustawach, dolna granica zdolności utrzymania z pracy w gospodarstwie rolnym jest różnie określana. Dla przykładu, w ustawie o ubezpieczeniu społecznym rolników wyższą składkę pobiera się w przypadku ubezpieczonego, którego gospodarstwo rolne jest większe niż 50 ha przeliczeniowych. $Z$ kolei w ustawie o promocji zatrudnienia i instytucjach rynku pracy bezrobotnym jest osoba, której gospodarstwo rolne obejmuje obszar użytków rolnych poniżej 2 ha przeliczeniowych.
} 
także nadmienić, że w środowisku wiejskim istnieje społeczne przyzwolenie dla unikania opłacania składek i podatków, wynikające z masowości występowania tego zjawiska.

\section{Zasady podlegania ubezpieczeniu społecznemu rolników}

Zgodnie z art. 1 ust. 1 u.s.r. ubezpieczeniem społecznym rolników objęci są: rolnik, jego małżonek oraz domownicy, czyli osoby współgospodarujące w gospodarstwie rolnym. Katalog osób podlegających ubezpieczeniu społecznemu rolników ma charakter zamknięty, co oznacza, że osoby spoza kręgu najbliższej rodziny zarobkujące $\mathrm{w}$ gospodarstwie rolnym podlegać będą ubezpieczeniu w ZUS. Przyjęte rozwiązanie należy uznać za systemowo niespójne. Rolnik wypełniając z mocy ustawy funkcje płatnika składek w ramach gospodarstwa rolnego część swoich pracobiorców tj. osoby nie będące członkami najbliższej rodziny zgłosi do ZUS, a pozostałych będących osobami bliskimi ubezpieczy w KRUS. Nie ma tutaj znaczenia, że każda z tych osób może wykonywać pracę tego samego rodzaju. Optymalnym rozwiązaniem byłoby ujednolicenie zasad podlegania ubezpieczeniu i włączenie rolników oraz osób z nimi współpracujących do ZUS.

Za rolnika zgodnie z art. 6 pkt 1 u.s.r. uznać należy pełnoletnią osobę fizyczną, zamieszkującą i prowadzącą na terytorium Rzeczypospolitej Polskiej, osobiście i na własny rachunek ${ }^{9}$, działalność rolniczą w pozostającym w jej posiadaniu gospodarstwie rolnym, $\mathrm{w}$ tym również $\mathrm{w}$ ramach grupy producentów rolnych, a także osobę, która przeznaczyła grunty prowadzonego przez siebie gospodarstwa rolnego do zalesienia ${ }^{10}$. Pojęcie to obejmuje nie tylko właściciela gospodarstwa rolnego, ale także np. dzierżawców. Rolnik po spełnieniu ustawowo określonych przesłanek zobowiązany jest zgłosić do ubezpieczenia chorobowego i wypadkowego, a także do ubezpieczenia emerytalnego i rentowego siebie oraz pozostałe osoby z nim współgospodarujące, o ile stale pracują w gospodarstwie rolnym i nie posiadają innych pozarolniczych tytułów ubezpieczenia. Objęcie ubezpieczeniem społecznym ma jak zauważył sąd apelacyjny w Gdańsku charakter deklaratoryjny, stąd też organ rentowy zarówno ZUS jak i KRUS ma prawo wydać z mocą wsteczną decyzję korygującą uprzednio ustalony bezpodstawnie tytuł ubezpieczenia (tj. wyłączyć ubezpieczonego z ubezpieczenia w KRUS, co będzie skutkowało objęciem takiej osoby ubez-

\footnotetext{
${ }^{9}$ W wyroku SA w Krakowie z dnia 21 sierpnia 2013, o sygn. akt: III AUa 1767/12 - sąd apelacyjny orzekł, że prowadzenie osobiście i na własny rachunek działalności rolniczej wskazuje na zawodowy, stały, osobisty i realizujący interes danej osoby charakter tej działalności

${ }^{10}$ Szerzej o pojęciu rolnika i gospodarstwa rolnego: K. Rodak, Definicja gospodarstwa rolnego $w$ świetle polskiego i unijnego ustawodawstwa, „Ubezpieczenia w Rolnictwie. Materiały i Studia”, nr 48 z 2013 r., s. 62-78.
} 
pieczeniem w ZUS ${ }^{11}$. Oprócz zgłoszenia do ubezpieczenia rolnik finansuje składkę za wszystkie osoby zgłoszone do ubezpieczenia w KRUS i współfinansuje składkę za ubezpieczonych w ZUS. Finansowanie składki na ubezpieczenie społeczne rolników wyłącznie przez rolnika wynika z założenia, że osoby objęte ubezpieczeniem w KRUS utrzymywane są z jednego źródła, a więc gospodarstwa rolnego z którego dochody w całości trafiają do rolnika. Jak zauważa I. Jędrasik-Jankowska, to czy małżonek rolnika będzie podlegał ubezpieczeniu jako rolnik czy też jako małżonek rolnika jest uzależnione od tego czy jest on współwłaścicielem gospodarstwa rolnego. Jeśli gospodarstwo rolne stanowi jego współwłasność, to będzie on podlegał ubezpieczeniu jako rolnik. Jeżeli gospodarstwo rolne nie będzie stanowiło jego współwłasności to z mocy ustawy będzie on podlegał ubezpieczeniu jako małżonek rolnika ${ }^{12}$, Do małżonka rolnika, zgodnie z art. 5 ustawy o u.s.r., stosuje się odpowiednio przepisy dotyczące ubezpieczenia rolnika, chyba że ten małżonek nie pracuje w gospodarstwie rolnika ani w gospodarstwie domowym, bezpośrednio związanym z tym gospodarstwem rolnym. $Z$ uwagi na szeroki katalog czynności uprawniających do przystąpienia do ubezpieczenia, należy uznać, że w praktyce to rolnik podejmuje decyzje czy jego małżonek będzie objęty ubezpieczeniem społecznym, a Kasie trudno jest wykazać to, że jego małżonek nie wykonywał czynności bezpośrednio związanych z gospodarstwem rolnym. Ubezpieczeniu społecznemu rolników podlegają także domownicy czyli osoby bliskie, które ukończyły 16 lat. Osoby te muszą pozostawać z rolnikiem we wspólnym gospodarstwie domowym lub zamieszkiwać na terenie jego gospodarstwa rolnego albo w bliskim sąsiedztwie oraz stale pracować w tym gospodarstwie rolnym i nie mogą być związane z rolnikiem stosunkiem pracy. Na szczególną uwagę zasługuje fakt, że domownikiem może być też osoba spoza wąsko rozumianej rodziny jak np. konkubent, który będzie osobą bliską w rozumieniu art. 6 pkt 2 u.s.r. To czy rolnik oraz domownicy będą objęci ubezpieczeniem, jest z kolei uzależnione od spełnienia dodatkowych przesłanek. Pierwszą z nich jest obszar gospodarstwa rolnego oraz rodzaj prowadzonej działalności. Obowiązkowo ubezpieczeniu podlega rolnik, którego gospodarstwo rolne obejmuje zgodnie z art. 7 ust. 1 pkt 1 u.s.r. oraz art. 16 ust. 1 pkt 1 u.s.r., obszar użytków rolnych powyżej 1 ha przeliczeniowego lub dział specjalny produkcji rolnej wymieniony w tabeli rodzajów i rozmiarów działów specjalnych produkcji rolnej stanowiącej załącznik do ustawy. W przypadku gospodarstwa rolnego poniżej 1 ha przeliczeniowego, rolnik oraz jego domownicy podlegają ubezpieczeniu dobrowolnie. Drugą przesłankę stanowi to, że rolnik oraz domownicy nie mogą, co do zasady, podlegać innemu ubezpieczeniu społecznemu, a także nie mogą

\footnotetext{
${ }^{11}$ Wyrok SA w Gdańsku z dnia 11 września 2013 r., III AUa 40/13, Legalis nr 744173.

${ }^{12}$ I. Jędrasik-Jankowska, K. Jankowska, Prawo do emerytury. Komentarz do ustaw z orzecznictwem, Warszawa 2011, s. 477.
} 
mieć ustalonego prawa do emerytury lub renty albo ustalonego prawa do świadczeń z ubezpieczeń społecznych.

Analizując uprawnienie przystąpienia do ubezpieczenia rolników gospodarujących na najmniejszych areałach, w pierwszej kolejności należy podkreślić socjalny aspekt włączenia ich do ubezpieczenia. W okresie transformacji ustrojowej brak dolnej granicy areału uprawniającego do ubezpieczenia w KRUS obniżał stopę bezrobocia, zapewniał najbiedniejszym rolnikom niskie emerytury i renty, w zamian za niską składkę. Jej wysokość stanowiła istotną zachętę do przystąpienia do ubezpieczenia społecznego, powodując jednocześnie zwiększenie liczby rolników podlegających ubezpieczeniu rolniczemu, a posiadających inne nieujawnione źródło dochodu. Obecnie, wobec niskiej stopy bezrobocia, powinno się dążyć do wyłączenia z KRUS rolników gospodarujących na areałach o powierzchni poniżej 1 ha przeliczeniowego. Postulowane rozwiązanie umożliwiłoby konsolidację gospodarstw rolnych, a ponadto brak zabezpieczenia społecznego spowodowałby to, że część rolników pozostająca w szarej strefie byłaby zmuszona ujawnić pozarolnicze źródło zarobkowania.

Warto podkreślić odrębne zasady jakie przewidziane zostały dla ubezpieczenia emerytalnego i rentowego oraz ubezpieczenia chorobowego i wypadkowego. Elementem spajającym oba podsystemy jest to, że obowiązek ubezpieczenia obejmuje rolnika oraz osoby współgospodarujące $\mathrm{w}$ gospodarstwie rolnym, to jest małżonka oraz domowników, o ile gospodarują oni na areale większym niż 1 ha przeliczeniowy lub prowadzą dział specjalny produkcji rolnej. Zauważyć należy ponadto, że zakres podmiotowy ubezpieczeń emerytalnego i rentowego oraz chorobowego i wypadkowego istotnie się różni. Oznacza to, że część rolników będzie objęta zarówno ubezpieczeniem emerytalno-rentowym oraz chorobowym i wypadkowym, natomiast pozostali rolnicy wyłącznie emerytalnym i rentowym bądź też jedynie ubezpieczeniem chorobowym i wypadkowym. Obowiązkiem wyłącznie ubezpieczenia emerytalnego i rentowego objęto m.in.:

- osobę pobierającą rentę strukturalną współfinansowaną ze środków pochodzących z Sekcji Gwarancji Europejskiego Funduszu Orientacji i Gwarancji Rolnej lub ze środków pochodzących z Europejskiego Funduszu Rolnego na rzecz Rozwoju Obszarów Wiejskich,

- małżonka osoby wymienionej powyżej, jeżeli renta strukturalna współfinansowana ze środków pochodzących z Sekcji Gwarancji Europejskiego Funduszu Orientacji i Gwarancji Rolnej lub ze środków pochodzących z Europejskiego Funduszu Rolnego na rzecz Rozwoju Obszarów Wiejskich wypłacana jest ze zwiększeniem na tego małżonka.

Prawo do wyłącznie dobrowolnego ubezpieczenia emerytalnego i rentowego przysługuje m.in.:

- osobie, która podlegała ubezpieczeniu jako rolnik i zaprzestała prowadzenia działalności rolniczej, nie nabywając prawa do emerytury lub renty z ubez- 
pieczenia, jeżeli podlegała ubezpieczeniu emerytalno-rentowemu przez okres co najmniej 12 lat i 6 miesięcy,

- osobie pobierającej rentę rolniczą z tytułu niezdolności do pracy jako rentę okresową,

- osobie, która podlegała ubezpieczeniu jako rolnik lub domownik i zaprzestała prowadzenia działalności rolniczej lub pracy w gospodarstwie rolnym w związku z nabyciem prawa do świadczenia pielęgnacyjnego lub specjalnego zasiłku opiekuńczego na podstawie ustawy z dnia 28 listopada $2003 \mathrm{r}$. o świadczeniach rodzinnych ${ }^{13}$ albo zasiłku dla opiekuna na podstawie ustawy z dnia 4 kwietnia 2014 r. o ustaleniu i wypłacie zasiłków dla opiekunów ${ }^{14}$ przez okres pobierania tego świadczenia albo zasiłku - do uzyskania 25-letniego okresu ubezpieczenia emerytalno-rentowego.

Żaden z tych podmiotów nie może przystąpić do ubezpieczenia chorobowego i wypadkowego. W ubezpieczeniu chorobowym i wypadkowym ubezpieczeniu podlegają z kolei osoby nieobjęte ubezpieczeniem emerytalnym i rentowym tj.:

- osoba, która będąc rolnikiem przeznaczyła grunty prowadzonego gospodarstwa rolnego do zalesienia;

- rolnik, domownik lub osoba, która przeznaczyła grunty do zalesienia jeżeli podlegają innemu ubezpieczeniu społecznemu albo mają ustalone prawo do emerytury lub renty lub do świadczeń z ubezpieczeń społecznych.

W ustawie o ubezpieczeniu społecznym rolników ustawodawca wyróżnił dwa jego działy tj. ubezpieczenie: chorobowe, wypadkowe i macierzyńskie (oznaczone w ustawie lit. A) oraz ubezpieczenie emerytalne i rentowe (oznaczone w ustawie lit. B). Podział ten jest jednak niespójny. Zgodnie bowiem $\mathrm{z}$ art. 18 pkt 7 u.s.r., zasiłek macierzyński stanowi świadczenie $\mathrm{z}$ ubezpieczenia emerytalnego i rentowego (typ B), a nie z ubezpieczenia macierzyńskiego (typ A).

Ubezpieczenie społeczne rolników wyróżnia odwrócona konstrukcja przystępowania do ubezpieczenia. W ubezpieczeniu w ZUS, każdy ubezpieczony jest obejmowany ubezpieczeniem emerytalnym i rentowym, które ma najszerszy zakres podmiotowy. Osoba podlegająca ubezpieczeniu emerytalnemu i rentowemu, może być objęta ubezpieczeniem chorobowym i wypadkowym. Osoba nie podlegająca ubezpieczeniu emerytalnemu i rentowemu, nie może przystąpić na swój wniosek np. wyłącznie do ubezpieczenia chorobowego. W ubezpieczeniu społecznym rolników to ubezpieczenie chorobowe i wypadkowe, ma najszerszy zakres podmiotowy. Cechą wyróżniającą jest także możliwość

\footnotetext{
${ }^{13}$ Ustawa z dnia 28 listopada 2003 r. o świadczeniach rodzinnych, Dz.U. z 2016 r., poz. 1518 ze zm.

${ }^{14}$ Ustawa z dnia 4 kwietnia 2014 r. o ustaleniu i wypłacie zasiłków dla opiekunów, Dz.U. z 2016 r., poz. 162 .
} 
przystąpienia wyłącznie do ubezpieczenia wypadkowego. Na mocy art. 7 ust. 3 u.s.r. rolnik, małżonek lub domownik, który podlega innemu ubezpieczeniu społecznemu albo ma ustalone prawo do emerytury lub renty lub do świadczeń z ubezpieczeń społecznych, może przystąpić wyłącznie do ubezpieczenia chorobowego i wypadkowego. Prawo do świadczeń takiej osoby zostaje jednak ograniczone wyłącznie do jednorazowego odszkodowania z tytułu stałego lub długotrwałego uszczerbku na zdrowiu i jednorazowego odszkodowania z tytułu śmierci ubezpieczonego wskutek wypadku przy pracy rolniczej lub rolniczej choroby zawodowej. W przypadku wystąpienia zdarzenia chronionego, a więc wypadku przy pracy rolniczej albo rolniczej choroby zawodowej, ubezpieczony nie nabędzie natomiast zasiłku chorobowego określonego w art. 9 pkt 2 u.s.r. Uprawnienie do przystąpienia do ubezpieczenia wypadkowego osób podlegających innemu ubezpieczeniu, wynika ze specyfiki pracy w rolnictwie i możliwości okresowego wykonywania prac w gospodarstwie rolnym przez członków rodziny, posiadających tytuł do ubezpieczenia w ubezpieczeniu powszechnym, dla których praca w gospodarstwie rolnym stanowi dodatkowe lub sezonowe źródło utrzymania lub też wynika z potrzeby doraźnej pomocy osobie najbliższej prowadzącej gospodarstwo rolne. Nie ma znaczenia to, czy ubezpieczeniem tym zostanie objęty rolnik, małżonek rolnika czy domownik. W przypadku zbiegu powszechnego ubezpieczenia wypadkowego z rolniczym ubezpieczeniem wypadkowym, ubezpieczony może podlegać jednocześnie ubezpieczeniu wypadkowemu zarówno w ZUS jak i w KRUS. Wątpliwości wzbudzać może jedynie fakt, że w przypadku wystąpienia wypadku przy pracy rolniczej lub rolniczej choroby zawodowej, ubezpieczony nabędzie prawo do zasiłku chorobowego z ogólnego stanu zdrowia wyłącznie z ZUS, a jednocześnie prawo do jednorazowego odszkodowania z KRUS. Ustawodawca powinien, moim zdaniem, wprowadzić zmiany mające na celu przyznanie ubezpieczonemu zasiłku chorobowego finansowanego z Funduszu Składowego Ubezpieczenia Społecznego Rolników.

\section{Zbieg ubezpieczenia emerytalno-rentowego, ubezpieczenia społecznego rolników oraz ubezpieczenia powszechnego}

Zbieg tytułów w ubezpieczeniu społecznym oznacza sytuację, gdy dana osoba wykonując kilka form aktywności zawodowej, spełnia w tym samym czasie warunki podlegania ubezpieczeniu z co najmniej dwóch tytułów do ubezpieczenia ${ }^{15}$. W przypadku zbiegu tytułów ubezpieczenia powszechnego i ubezpieczenia społecznego rolników ustawodawca wprowadził zasadę pryma-

\footnotetext{
${ }^{15}$ Szerzej: T. Bińczycka-Majewska, Zbieg tytułów ubezpieczenia emerytalnego i rentowego w nowym systemie ubezpieczeń spotecznych, „PiZS” nr 12 z 2000 r., s. 2 i nast.
} 
tu systemu powszechnego ${ }^{16}$. W myśl powoływanej zasady, obowiązek ubezpieczenia rolniczego jest wyłączony, jeżeli zbiega się ono z obowiązkiem innego ubezpieczenia społecznego ${ }^{17}$. Reguła ta została wyrażona wprost $\mathrm{w}$ art. 5 ust. 1 ustawy o s.u.s. Zgodnie z treścią powoływanego przepisu, rolnik, małżonek lub domownik rolnika mogą podlegać ubezpieczeniu społecznemu rolników wyłącznie wtedy, jeżeli nie podlegają obowiązkowi ubezpieczeń społecznych na podstawie ustawy o s.u.s., a więc nie posiadają tytułu do ubezpieczenia w ZUS. Przepis ten został wzmocniony przez art. 7 oraz art. 16 u.s.r., gdzie ustawodawca wskazuje, że rolnik lub domownik może przystąpić do ubezpieczenia w KRUS, jeżeli nie podlega innemu ubezpieczeniu społecznemu lub nie ma ustalonego prawa do emerytury lub renty albo nie ma ustalonego prawa do świadczeń z ubezpieczeń społecznych. A zatem ubezpieczony podlegając ubezpieczeniu w ZUS, nie może co do zasady jednocześnie podlegać ubezpieczeniu społecznemu rolników. Prymat systemu powszechnego wynika po pierwsze z faktu, że składka opłacana na ubezpieczenie społeczne rolników jest kilkukrotnie niższa, niż w przypadku osób objętych ubezpieczeniem powszechnym. Po drugie, celem przyjętej regulacji jest objęcie zainteresowanego ubezpieczeniem społecznym w taki sposób, aby składka na ubezpieczenie była finansowana przez płatnika i ubezpieczonego (składka na ZUS), a nie budżet państwa (składka na KRUS). Warto ponadto zaznaczyć, że jeżeli po rozpoczęciu działalności rolniczej ubezpieczony uzyska tytuł do ubezpieczenia w ZUS, to z mocy ustawy zostanie wyłączony z ubezpieczenia społecznego rolników i objęty ubezpieczeniem powszechnym. Zasada prymatu systemów nie ma jednak charakteru absolutnego, co oznacza, że ustawodawca wprowadza od niej wyjątki. Pierwszy wyjątek stanowi zbieg ubezpieczenia społecznego rolników i działalności pozarolniczej. Do 2004 r. na mocy art. 5a u.s.r. rolnik lub domownik niebędący pracownikiem i niepozostający w stosunku służbowym, podlegając ubezpieczeniu w KRUS w pełnym zakresie z mocy ustawy, nieprzerwanie co najmniej 1 rok, mógł podjąć pozarolniczą działalność gospodarczą i nadal podlegać ubezpieczeniu rolniczemu. Rolnik lub domownik mógł jednak zmienić tytuł ubezpieczenia, gdy złożył w ZUS lub KRUS oświadczenie, o wyborze podlegania ubezpieczeniu społecznemu z tytułu pozarolniczej działalności gospodarczej na zasadach ogólnych. Na skutek ówcześnie obowiązujących przepisów, ponad

\footnotetext{
${ }^{16}$ W wyroku SA w Łodzi z dnia 16 stycznia 2013 r., III AUa 834/12 - sąd apelacyjny orzekł, że jeżeli rolnik podlega innemu ubezpieczeniu społecznemu, to nie podlega z mocy ustawy ubezpieczeniu społecznemu rolników. Właściwa wykładnia cytowanych przepisów prowadzi do wniosku, że podleganie ubezpieczeniu społecznemu z innego tytułu „wyprzedza” ubezpieczenie rolnicze. Wyjątek od prymatu podlegania innym ubezpieczeniom społecznym w razie ich zbiegu $\mathrm{z}$ ubezpieczeniem społecznym rolników przewiduje art. 5a ustawy o ubezpieczeniu społecznym rolników.

${ }^{17}$ Tak np. I. Jędrasik-Jankowska, Ubezpieczenie społeczne, t. 1 Część ogólna, Warszawa 2003, s. 113.
} 
118 tys. osób prowadzących pozarolniczą działalność gospodarczą pozostawało w ubezpieczeniu w KRUS. Dokonana w 2004 r. nowelizacja ${ }^{18}$ art. 5a u.s.r. przyznała prawo pozostania w ubezpieczeniu społecznym rolników osobie rozpoczynającej prowadzenie działalności pozarolniczej, jeżeli ta podlegała uprzednio nieprzerwanie przez co najmniej 3 lata ubezpieczeniu rolniczemu z mocy ustawy w pełnym zakresie. Trzyletni staż ubezpieczenia rolniczego, jak zauważył sąd apelacyjny w Białymstoku powinien przypadać bezpośrednio przed dniem rozpoczęcia pozarolniczej działalności gospodarczej, a nawet krótka przerwa w podleganiu temu ubezpieczeniu uniemożliwia jego kontynuowanie w sytuacji jednoczesnego prowadzenia działalności gospodarczej ${ }^{19}$. Tak długi okres, znacząco ogranicza możliwość przystąpienia do ubezpieczenia w KRUS przez przedsiębiorców. Jak wskazał sąd apelacyjny w Szczecinie, art. 5a u.s.r. wskazuje wyłącznie na prawo wyboru systemu podlegania ubezpieczeniu społecznemu, nie statuuje zasady prymatu podlegania rolniczemu ubezpieczeniu społecznemu w przypadku zbiegu tego ubezpieczenia z innym tytułem ubezpieczenia społecznego ${ }^{20}$. Warto także zaznaczyć, że w powoływanym przepisie ustawodawca wprowadził dodatkowe obostrzenia, w tym w szczególności maksymalną kwotę należnego podatku dochodowego za poprzedni rok podatkowy od przychodów z pozarolniczej działalności gospodarczej tzw. roczną kwotę graniczną ${ }^{21}$. Po jej przekroczeniu rolnik jest wyłączany z ubezpieczenia w KRUS i jest obejmowany ubezpieczeniem w ZUS, chyba że zaprzestanie on prowadzenia pozarolniczej działalności gospodarczej, w sposób trwały lub okresowy, przed upływem terminu na złożenie tego zaświadczenia albo oświadczenia. Na skutek uszczelnienia systemu liczba rolników prowadzących działalność pozarolniczą zmniejszyła się w 2005 roku do 48 tys., a obecnie wynosi ona 84 tys. osób ${ }^{22}$.

Drugi wyjątek stanowi określony w art. 5 b u.s.r. zbieg działalności rolniczej oraz umowy zlecenia. Wyjątek ten został wprowadzony ustawą o zmianie ustawy o ubezpieczeniu społecznym rolników oraz niektórych innych ustaw z dnia 23 października $2014 \mathrm{r}^{23} \mathrm{~W}$ myśl dodanego przepisu rolnik lub domownik, który podlegając ubezpieczeniu rolniczemu w pełnym zakresie z mocy ustawy i zostanie objęty powszechnym ubezpieczeniem społecznym z tytułu wykony-

\footnotetext{
${ }^{18}$ Ustawa z 2 kwietnia 2004 r. o zmianie ustawy o ubezpieczeniu społecznym rolników oraz zmianie niektórych innych ustaw, Dz.U. z 2004 r. Nr 91, poz. 873.

${ }^{19}$ Wyrok SA w Białymstoku z dnia 21 sierpnia 2013 r., III AUa 190/13, Legalis nr 735759.

${ }^{20}$ Wyrok SA w Szczecinie z dnia 24 czerwca 2014 r., III AUa 1068/13, Legalis nr 1219012.

${ }^{21}$ Obecnie roczna kwota graniczna wynosi 3258 zł. Obwieszczenie Ministra Rolnictwa i Rozwoju Wsi z dnia 23 maja 2016 r. w sprawie rocznej kwoty granicznej, M.P. z 2016 r., poz. 483.

${ }^{22} \mathrm{http} / /$ www.krus.gov.pl/krus/krus-w-liczbach/liczba-osob-ubezpieczonych-w-kasie-prowadzacych-pozarolnicza-dzialalnosc-gospodarcza/ (dostęp: 01.04.2017).

${ }^{23}$ Ustawa z dnia 23 października 2014 r. o zmianie ustawy o systemie ubezpieczeń społecznych oraz niektórych innych ustaw, Dz.U. z 2014 r., poz. 1831.
} 
wania umowy zlecenia, ma prawo nadal podlegać ubezpieczeniu społecznemu rolników, jeżeli przychód osiągany z tego tytułu w rozliczeniu miesięcznym nie przekracza kwoty minimalnego wynagrodzenia za pracę. Celem wprowadzonej regulacji było zagwarantowanie rolnikowi możliwości kontynuowania ubezpieczenia w KRUS, w sytuacji gdy dodatkowa działalność ma np. dorywczy charakter, czy też stanowi dodatkowe źródło zarobkowania. Nowelizację tę należy ocenić zarówno pozytywnie jak i negatywnie. Z pewnością pozytywnie należy ocenić fakt, że ustawodawca nie uniemożliwia rolnikom wykonywania dorywczych pozarolniczych aktywności zarobkowych. Jest to szczególnie istotne, $\mathrm{z}$ uwagi na niskie areały gospodarstw rolnych. $Z$ drugiej jednak strony, w środowisku rolniczym istnieje znaczna liczba osób pozostających w tzw. szarej strefie. Zbieg umowy zlecenia z działalnością rolniczą, w znaczący sposób utrudnia wykrywanie osób dla których praca poza rolnictwem stanowi podstawowe, a często także i jedyne źródło zarobkowania. Organy kontrolujące płatników składek coraz częściej spotykają się z sytuacją, gdy rolnicy wykonują w ramach zlecenia „pełnoetatową pracę”, dobrowolnie godząc się na oficjalnie kilkukrotnie niższe wynagrodzenie, uzupełniane przez zleceniodawcę ,,pod stołem". Wykrycie tego typu patologii, po nowelizacji przepisów jest niezwykle trudne.

Drugi wyjątek stanowi możliwość łączenia działalności rolniczej oraz zasiadania $w$ radach nadzorczych. Przyznanie tego uprawnienia wynika przede wszystkim z faktu, że zasiadanie w radach nadzorczych wyłączałoby możliwość podlegania ubezpieczeniu społecznemu rolników i wydłużyłoby okres przez jaki rolnik, najczęściej zaangażowany politycznie, musiałby prowadzić działalność rolniczą. Z uwagi jednak na niewielki odsetek osób łączących oba tytuły ubezpieczenia i z reguły krótkotrwały charakter zbiegu, przyjęte rozwiązanie należy ocenić pozytywnie.

\section{Zasady obliczania zbiegających się świadczeń}

Podleganie przez dwuzawodowca dwóm różnym systemom zabezpieczenia społecznego wiąże się ze skomplikowanymi zasadami obliczania świadczenia emerytalnego. Warto wskazać, że okresy ubezpieczenia w obu systemach mogą występować nie tylko naprzemiennie, ale także ubezpieczony może podlegać obu systemom jednocześnie. Zbieg okresów ubezpieczenia rolniczego i powszechnego stanowi wyjątek od ogólnie przyjętej zasady, że w przypadku prawa do dwóch świadczeń z ubezpieczenia społecznego, ubezpieczonemu przysługuje świadczenie wyższe lub korzystniejsze. Osoby posiadające status dwuzawodowca i odpowiednio długi okres podlegania ubezpieczeniu społecznemu rolników nabywają prawo do wypłaty dwóch niezależnie obliczanych świadczeń, a więc np. emerytury rolniczej z KRUS oraz emerytury z ZUS. 
Ustawodawca wprowadził jednak niezwykle restrykcyjne zasady zaliczania stażu rolniczego bądź do emerytury rolniczej, bądź też doliczenia go do emerytury w systemie powszechnym. Po pierwsze prawo do emerytury rolniczej przysługuje wyłącznie osobie, która posiada minimalne wskazane w ustawie okresy ubezpieczenia w KRUS. Ustawodawca wyłączył możliwość zaliczenia do ubezpieczenia rolniczego okresów ubezpieczenia w ZUS. A zatem osoba, która legitymuje się stażem niższym niż 25 lat podlegania ubezpieczenia społecznego rolników nie nabędzie emerytury z KRUS.

$\mathrm{Z}$ drugiej strony osoba taka będzie mogła uwzględnić staż ubezpieczeniowy w KRUS doliczając go zgodnie $z$ art. 26a ustawy emerytalnej ${ }^{24}$ do emerytury z ZUS. W myśl powoływanego przepisu, rolnik który legitymuje się okresami podlegania ubezpieczeniu społecznemu rolników krótszymi niż 25 lat, ma prawo złożyć wniosek o zwiększenie emerytury za okresy opłacania składek na Fundusz Emerytalny Rolników, Fundusz Ubezpieczenia Społecznego Rolników i ubezpieczenie emerytalno-rentowe w KRUS. Uprawnienie to nie przysługuje rolnikom, którzy posiadają staż dłuższy, gdyż osoby takie po osiągnięciu wieku emerytalnego, spełniając przesłankę stażu, nabędą emeryturę z KRUS. Ponadto, z powoływanego przepisu wynika, że ustawa uniemożliwia podział stażu i uwzględnienie np. 25 lat w KRUS a pozostałych 10 lat w ZUS. SN w uchwale z dnia 3 października $2012 \mathrm{r} .^{25}$ wskazał, że zwiększenie to nie obejmuje okresów podlegania ubezpieczeniu społecznemu rolników, w których rolnik zwolniony był od obowiązku opłacania składki na ubezpieczenie społeczne rolników.

\section{Podsumowanie}

Zbieg tytułów ubezpieczenia powszechnego i rolniczego powoduje liczne problemy natury interpretacyjnej. Aby uporządkować zasady podlegania ubezpieczeniom przez dwuzawodowców, ustawodawca powinien zagwarantować ubezpieczonym w KRUS możliwość doliczenia okresów podlegania innemu ubezpieczeniu. Umożliwiłoby to nabycie jednego świadczenia emerytalnego. Postulowane rozwiązanie zwiększyłoby liczbę rolników ujawniających dodatkowe źródło dochodów. Docelowo jednak, za optymalne rozwiązanie uznać należy włączenie rolników do powszechnego systemu zabezpieczenia społecznego i likwidacja KRUS. Postulowane rozwiązanie znacząco uprościłoby regulację zasad podlegania ubezpieczeniu społecznemu. Jednakże bez koniecznych przeobrażeń, w postaci konsolidacji gospodarstwa rolnych, postulowane przeze mnie rozwiązanie, ze względów politycznych, nie będzie możliwe.

\footnotetext{
${ }^{24}$ Ustawa z dnia 17 grudnia 1998 r. o emeryturach i rentach z Funduszu Ubezpieczeń Społecznych, Dz.U. z 2016 r., poz. 887 ze zm.

${ }^{25}$ Uchwała SN z dnia z dnia 3 października 2012 r. o sygn. III UZP 4/12 OSNP 2013/5-6/58.
} 


\section{Bibliografia}

\section{Literatura}

Bińczycka-Majewska T., Zbieg tytułów ubezpieczenia emerytalnego i rentowego w nowym systemie ubezpieczeń społecznych, „PiZS” nr 12 z 2000 r.

GUS, Rocznik statystyczny rolnictwa 2015, Warszawa 2015.

Jędrasik-Jankowska I., Jankowska K., Prawo do emerytury. Komentarz do ustaw z orzecznictwem, Warszawa 2011.

Jędrasik-Jankowska I., Ubezpieczenie społeczne, t. 1 Część ogólna, Warszawa 2003.

Rodak K., Definicja gospodarstwa rolnego w świetle polskiego $i$ unijnego ustawodawstwa, „Ubezpieczenia w Rolnictwie. Materiały i Studia”, nr 48 z 2013 r.

Wierzbowski B., Status socjalny rolnika, [w:] Prawo rolne. A. Stelmachowski (red.), Warszawa 2005.

\section{Akty prawne}

Obwieszczenie Ministra Rolnictwa i Rozwoju Wsi z dnia 23 maja 2016 r. w sprawie rocznej kwoty granicznej, M.P. z 2016 r., poz. 483.

Ustawa z 2 kwietnia 2004 r. o zmianie ustawy o ubezpieczeniu społecznym rolników oraz zmiana niektórych innych ustaw, Dz.U. z 2004 r. Nr 91, poz. 873 ze zm.

Ustawa z dnia 13 października 1998 r. o systemie ubezpieczeń społecznych, Dz.U. z 2016 r., poz. 963 ze zm.

Ustawa z dnia 17 grudnia 1998 r. o emeryturach i rentach z Funduszu Ubezpieczeń Społecznych, Dz.U. z 2016 r., poz. 887 ze zm.

Ustawa z dnia 20 grudnia 1990 r. o ubezpieczeniu społecznym rolników, Dz.U. z 2016 r., poz. 277 ze zm.

Ustawa z dnia 23 października 2014 r. o zmianie ustawy o systemie ubezpieczeń społecznych oraz niektórych innych ustaw, Dz.U. z 2014 r., poz. 1831.

Ustawa z dnia 28 listopada 2003 r. o świadczeniach rodzinnych, Dz.U. z 2016 r., poz. 1518 ze zm. Ustawa z dnia 4 kwietnia 2014 r. o ustaleniu i wypłacie zasiłków dla opiekunów, Dz.U. z 2016 r., poz. 162.

\section{Orzeczenia sądowe}

Uchwała SN z dnia z dnia 3 października 2012 r., III UZP 4/12 OSNP 2013/5-6/58. Wyrok SA w Białymstoku z dnia 21 sierpnia 2013 r., III AUa 190/13, Legalis nr 735759. Wyrok SA w Gdańsku z dnia 11 września 2013 r., III AUa 40/13, Legalis nr 744173. Wyrok SA w Krakowie z dnia 21 sierpnia 2013 r., III AUa 1767/12, Lex nr 1363258. Wyrok SA w Łodzi z dnia 16 stycznia 2013, III AUa 834/12, Lex nr 1271899.

Wyrok SA w Szczecinie z dnia 24 czerwca 2014 r., III AUa 1068/13, Legalis nr 1219012.

\section{Źródla internetowe}

http://www.krus.gov.pl/krus/krus-w-liczbach/liczba-osob-ubezpieczonych-w-kasie-prowadzacych-pozarolnicza-dzialalnosc-gospodarcza/ (dostęp: 01.04.2017).

http://www.krus.gov.pl/krus/krus-w-liczbach/wymiar-kwartalnych-skladek-na-ubezpieczenie -spoleczne-rolnikow/ (dostęp: 01.04.2017).

http://www.zus.pl/ (dostęp: 01.04.2017). 